\title{
Staging Revolution: Form and Violence in La noche de los asesinos
}

\section{Gina Beltrán}

I am interested above all else in man, man as he shows himself, man as he is produced every day (...) I look at man in his critical attitudes, in a key position, in the moment of possible transformations and possible cataclysms. José Triana ${ }^{1}$

"The theatre in Cuba since 1959 is a product of the Revolution" ("Estorino" 57). These words, with which George F. Woodyard begins his article on Abelardo Estorino's theatre, assertively situate the revolution as the imminent framework through which all Cuban cultural production after 1959 is categorized, approached, and analyzed. The dramaturgical production of José Triana is no exception. The present article focuses on Triana's $L a$ noche de los asesinos (1965) in an attempt to look at the revolution not only as the historical and political context of the play, but also, and most importantly, as its form. The form of revolution implies violence and a shattering of structures and paradigms that significantly relate to Triana's play's shifting and unstable dramatic spaces. Triana creates a complex performative space that turns La noche into a dramaturgical exploration of revolution as violent change and transformation. I use Franz Fanon's theoretical understanding of structural violence to investigate how La noche offers important insights into the experiential and emotional processes of the Cuban subject within the historical process of the revolution.

\section{Reading La noche de los asesinos}

In La noche, three siblings, Lalo, Cuca, and Beba, enact the assassination of their parents in a repetitive and convoluted game. The action takes 
place in an isolated room that is either an attic or basement. The indefinite temporality of the play makes it impossible for the spectator to determine whether the murder has truly occurred and the game constitutes a ritualization of the criminal act, or if the game is a rehearsal for a future murder that has not or will never take place. ${ }^{2}$ In the first of two acts, Lalo initiates the game and incites his two sisters to participate. Cuca resists at first, but then slowly starts to give in to Lalo's capricious demands. The action reaches its climax when Lalo murders their parents. In the second act, the three siblings continuously exchange roles, acting as the policemen that come to investigate the crime, the district attorney who judges Lalo, various family friends, and their own parents at different stages of their life. These varied role-playing sequences create a complex performative space that emotionally burdens and exhausts the siblings. The play concludes with Beba's frightening assertion: "Ahora me toca a mí" (128), which denotes the cyclic character of both game and play.

La noche premiered on November 4, 1966, during the $6^{\text {th }}$ Havana Festival of Latin American Theatre. ${ }^{3}$ The play was quick to receive the critical attention that turned it into one of the most discussed and performed Latin American plays. However, this critical attention maintained divergent viewpoints that granted the play an ambiguous position in the Cuban theatrical scene. Critics read and interpreted the play predominantly through a political lens that fixed the play within ideological boundaries. At one side of the spectrum, critics regarded the play as an allegory of the times that preceded the revolution and as a hostile view of the socio-political situation under the Batista regime. ${ }^{4}$ Frank Dauster states that Triana is "profoundly critical of the stagnancy that led to the need for revolt, of the blind religiosity, political corruption, and family decay that prevailed" (184). Triana himself supported this interpretation by stating that he began to write the play in the mid-fifties and that he sought to reaffirm the revolution. Moreover, the stage direction that opens the play, "Epoca: cualquiera de los años 50," has traditionally been regarded as an important textual detail that hints at the play's allegiance to the Cuban revolution. Nonetheless, this critical approach did not prevail during Triana's dramaturgical career. On the contrary, Triana experienced an intellectual marginalization that eventually culminated with his exile to France in 1980.

During the $60 \mathrm{~s}$ and $70 \mathrm{~s}$, critics tended to regard the play as a counterrevolutionary text. In her insightful article, "La noche de los asesinos: Playscript and Stage Enactment," Kirsten Nigro posits that the cyclical domestic conflict of the play suggests that recent Cuban history is a perpetuation of successive tyrannies in which one dictatorship replaces another "ad infini- 
tum" (47). ${ }^{5}$ Although Nigro merely offers this approach as a possible reading to which she does not subscribe, such lines of argumentation constitute the core of important critical works that regard Triana as a counterrevolutionary playwright. For instance, Román V. de la Campa examines the local reception of La noche and contends that Triana failed to capture the revolutionary spirit of the new Cuban society. Similarly, other critics saw in Triana's play a poignant critique of the revolution's institutionalizing process. ${ }^{6}$ One of the theoretical backbones common to these critiques functioned at an ideological level; the gist of postulating history as a cyclic process fundamentally refuted the revolutionary principle of history as a linear development that could and should be modified. From this perspective, La noche contradicted fundamental axioms of revolutionary ideology.

Beyond Cuba and such ideologically polarized readings, Triana's play was widely acclaimed in Europe, beginning with its first international performance in England in 1968, when the Royal Shakespeare Company staged it under the title The Criminals. ${ }^{7}$ The play was seen as a Latin American version of the theatre of the absurd. Critics saw in its aesthetic composition avant-gardist traits that formally and philosophically displayed similarities with the theatrical experimentations of Samuel Beckett, Eugène Ionesco, and Jean Genet. This critical appreciation resonated with Latin American critics, who began to see Triana as part of a broader theatrical movement on the Latin America stage. In his 1969 pioneer article "The Theatre of the Absurd in Spanish America," Woodyard argues that since the mid-fifties the Spanish American theatrical scene saw a renewed vitality through plays that utilized sophisticated forms, avant-gardist devices, and complex dramatic structures that transcended national boundaries. Additionally, he sustains, these innovative forms escaped the melodramatic and sensationalist tone of previous plays and worked towards elucidating the human condition and becoming "significant commentaries on a universal scale" (183). ${ }^{8}$

To further our understanding of La noche's critical reception, I turn to Diana Taylor's The Theatre of Crisis: Drama and Politics in Latin America. Taylor contends that much of the criticism written about Latin American theatre has contributed to diminish the way this theatre is perceived. She identifies two specific critical perspectives to develop her argument. The first, she explains, is primarily led by American and European commentators who during the sixties and seventies judged Latin American plays exclusively as texts and "tended to decontextualize the drama, focusing on universal themes and recognizable models and traditions" (14). In her view, this critical approach promotes the notion of these texts as products of an underdeveloped 
world (16). The second perspective involves a political process in which theatre is regarded as a political weapon and instrument of liberation. Taylor focuses on Augusto Boal's well-known theory of the theatre of the oppressed as an important and influential critical perspective that simplifies the theatrical phenomenon to an element of social change (17-18).

These two critical perspectives serve as a theoretical framework to organize La noche's critical reception. The interpretations of La noche as a Latin American version of the theatre of the absurd represent the first perspective, in which the focus on European aesthetic forms reduces the play to a de-contextualized and universalist text. Correspondingly, the readings of Triana's play based on its ideological allegiance represent the second critical perspective, which views the play through a political lens and determines its value as an agent of social change in support of the revolution. This latter tendency was not exclusive to Cuba, but also extensively developed across Latin America. A vital example is Woodyard's and Leon F. Lyday's seminal work, Dramatists in Revolt: The New Latin American Theatre. Woodyard and Lyday contend that "While contemporary drama in Latin America is perhaps best characterized by its diversity — in type and theme - the playwrights who have created this drama are united by a spirit of revolution" (xiii).

The two contrasting critical approaches identified by Taylor can be summarized as either the aesthetic universalist viewpoint or the socio-political one. Latin American dramatic criticism has traditionally overemphasized either form or context, failing to produce an integral understanding of many Latin American plays. This problem is particularly relevant to the experimental theatre of the $60 \mathrm{~s}$, which tended to employ sophisticated formal devices to create highly ambiguous worlds that obscure evident political ideology.

The tendency to emphasize the play's contextual referents (socio-political reality) allows for La noche to continue being read as a "self-contained set of rituals meant at some level to stand in for the outside world" (Gladhart 192). The assumption that the play's action symbolically represents an outside referential obscures the play itself and its intricate modes of encoding reality. I propose that revolution is not only La noche's political context, but also, and most importantly, its form. As we shall see, the play's dramatic action constitutes the process of revolution itself. It is not an allegorical representation of the Cuban revolution, but rather a dramaturgical exploration of the violent - psychological, emotional, structural, and historical — change and transformation that revolution entails. 


\section{Shifting performances and collapsing structures}

La noche's dramatic action is guided by a complex performative space that increasingly overlaps the characters' reality with the fiction of their game. Early in the first act, when Cuca is still hesitant about participating in the game, Lalo pretends that two of their parents' vexing friends, Margarita and Pantaleón, have unexpectedly arrived and blames Cuca for inviting them. Cuca is terrified and does not know how to enter the game. She manages, however, to momentarily step into her role and pretend that she has indeed invited the couple. Then Lalo reproaches her for befriending the unwelcomed couple, but Cuca is unable to resist the emotional charge of the game and steps out of her role:

CUCA. (Fuera del juego.) No sigas.

LALO. Hazlo.

CUCA. Me sacas de quicio.

LALO. Ten coraje.

CUCA. (Sofocada.) Perdóname, te lo suplico.

BEBA. ( $A L A L O$.) Déjala un rato.

CUCA. (Sollozando.) No tengo la culpa. Soy así. No puedo cambiar. Ojalá pudiera. (79)

Cuca's sudden detachment from the game marks one of the many instances in which the action oscillates between the imaginary characters they impersonate and the siblings' reality. Although such change is indicated here through a specific stage direction- "Fuera del juego"- the tension between game and reality still constitutes an ambiguous instance of varied possibilities. Cuca's plea to Lalo for forgiveness reflects her incapacity to commit to the game, but it could also be interpreted as part of the game. This would imply that Cuca's emotional breakdown actually constitutes mere pretence and that her apparent weakness is part of her acting. Such reading is congruent with the play's ambivalent dynamics, as words and behaviors increasingly point to different meanings and frames of reference.

This becomes evident in the first act's closing line uttered by Beba, "La primera parte ha terminado" (100), which echoes the first line in the play: "La representación ha empezado" (75). While these two statements explicitly refer to the characters' game, they also refer to a space beyond the characters' reality. Beba's words allude both to the spectator's theatrical experience and to the dramatic structure of the play. The play's ambivalent language destabilizes fixed meanings and points to different contexts that 
obliterate boundaries within and beyond the stage. On the one hand, the spectator can never be certain whether a character is role-playing in the game or whether she is simply acting within her own reality. On the other hand, one must question the siblings' awareness of their role-playing, which at times seems to enter the spectator's reality. In sum, La noche's dramatic action is characterized by a general state of ambiguity that problematizes a fixed and determinate notion of reality.

In the above-cited fragment, Cuca insists that she cannot help being who she is. Her phrase, better suited for a melodrama, becomes a highly ironic remark within the play's performative context. The characters' identity is constantly mediated by a multitude of representations that weakens their identity and invalidates a fixed notion of selfhood. In reality, what Cuca and her siblings cannot help is their embodiment of a heterogeneous array of impersonations. At times, the spectator cannot determine whether the spoken words are uttered by one of the siblings in reference to her own reality, or whether they are uttered by one of the many imaginary identities that participate in the game. Hence, the game develops through uncertain acts of ventriloquism that further undermine the characters' identity. This leads to a fragmented perception that prevents the spectator from perceiving any of the characters as a whole and integral being, but rather as "figuras de un museo en ruinas" (74), as Triana's opening stage direction indicates. As ontologically fragmented beings, the characters stand like ruins in the threshold between existence and inexistence. Lalo, Cuca, and Beba are specters of their own selves, bodies inhabited by ephemeral others.

This view of the three siblings as vulnerable and broken beings leads us to question readings of $\mathrm{La}$ noche that attribute overt intentions to the characters. In this regard, Dauster contends that Lalo's character represents absolute rebellion:

Cuca, in contrast, defends her parents and accepts their world; her participation is reluctant, while Beba oscillates between the two attitudes, unable to resolve her hatred of the parents' pedestrian world, their rancors and pettiness, and the alternatives offered by Cuca and Lalo: total acceptance or total rebellion. (179)

Dauster attributes a fixed position to Lalo and Cuca, overlooking the fact that their constant impersonations do not add up to a coherent self capable of carrying out consequent actions. He does not take into account that Cuca's initial reluctance to join in Lalo's game transforms in the second act into an eager desire to lead the murderous game. Moreover, the shifting of the 
characters from a state of passivity to a state of aggressive rebellion is by no means exclusive to Beba; all three oscillate within the play's unfixed space of ambiguity.

Nonetheless, Dauster and other critics are correct in noting a latent desire for rebellion. Lalo expresses this desire early in the play, when he protests their parents' over-bearing control and his lack of autonomy within the household: "¿No se te ha ocurrido nunca lo que significa que tú puedas pensar, decidir y hacer por tu propia cuenta?" (86). His words can indeed be read as part of a generational conflict in which he must challenge and break his parents' authority to assert his own autonomy, yet the play's complex configuration begs for a different reading. We can begin to trace the possible meanings of rebellion in the play by focusing on the following fragment, in which Cuca plays the mother, Lalo (intermittently) the father, and Beba struggles to play herself as a young girl:

CUCA. (...) "Únete, no seas boba. Nos divertiremos". Es inconcebible. Lo estoy viendo y me parece una tomadura de pelo. Vamos, levántate. (La ayuda a pararse. Como la madre.) Recuerda que estás delante de una visita. (Al visitante imaginario.) Son tan malcriados, tan insoportables... (A BEBA. Llevándola hasta la silla donde estaba sentada.) Muñeca mía, compórtate como la niña fina que eres, como una niñita educada...

BEBA. (Como una niña.) Me quiero ir.

CUCA. (Como la madre.) ¿A dónde quieres ir, nenita?

LALO. (Fuera del juego. Violento.) Esto no es así. Esto no sirve.

CUCA. (Como la madre.) No te sulfures, Alberto.

LALO. Me dan deseos de estrangularla.

CUCA. (Como la madre.) Paciencia, hombre.

BEBA. (Llorando.) Tengo miedo.

LALO. ¿Miedo, a qué? ¿Por qué llora?

CUCA. (Como la madre.) Ignórala. Es lo mejor, Alberto.

LALO. (Como el padre. Con gestos torpes.) Algunas veces... (Se golpea la rodilla derecha.) Compréndeme, mujer.

CUCA. (Como la madre.) ¿Cómo no voy a comprenderte? (Suspira.) Ay, Alberto, tú también eres un niño. ¡Si lo sabré yo, Angelita!

BEBA. (Como una furia. En pie.) ¡Basta!... Quisiera reventar. Quisiera volar. No soporto este encierro. Me ahogo. Voy a morir y detesto sentirme aplastada, hundida en este cuarto..., ay no puedo más... Por favor, yo les suplico, déjenme. (96-97) 
In this fragment, Cuca serves as the representational frame. She plays the role of the mother, who is acting in front of imaginary guests to follow social decorum and thus reduces Beba's nervous attempt to leave the game to a childish tantrum. Lalo wants to attack Beba for her erratic behavior, but soon after he resumes his impersonation of the father and continues the game with clumsy gestures. The hesitance between adherence to the game and withdrawal conflates the space of the game with the characters' reality. By the time Beba furiously cries that she can no longer tolerate the suffocating situation and begs to be left alone, her words occupy a space of variable boundaries that connects different possibilities. Her words can simultaneously be taken as a cry against the parents' stifling order, against the game, or as a reaction against the confined physical space in which they find themselves. In broader terms, her words can also be read as a protest against the world and the stage. Nevertheless, the crucial element is to understand that the game's complex structure prevents Beba's protest from being pinned down to a single specific context. This scene thus reveals that it is clearly a simplification to speak of the characters' explicit desire for rebellion uniquely as a collective cry against the parents' authority.

As earlier discussed, many critics have interpreted La noche as an allegorical play either in favor of or against the Cuban revolution. ${ }^{9}$ Countering these views, I contend that Triana's play is not merely guided by a revolutionary intent. Instead, I argue that the play's dramatic action in all its complexity is symptomatic of the turbulence and chaos that a revolution produces in its processes of realization. Furthermore, I propose that within this chaotic context the rebellious desire of the characters constitutes an attempt to assert their own sense of being - their own subjectivity - in a world of collapsed structures and shattered paradigms.

La noche's most representative line is "La sala no es la sala. La sala es la cocina," which the characters repeat throughout. These words have been interpreted traditionally as the paradigmatic example of the siblings' rebellious urge to subvert the existing order and create a new one, but it is necessary to examine two instances in which this phrase appears in the dialogue to see the limitations of such reading. Towards the end of the first act, Lalo begins to rub one knife against another, instilling the action with a screeching rhythm that leads the characters to "un clímax delirante." Soon after Cuca begins to sing in a faint voice "La sala no es la sala. La sala es la cocina," as both sisters give their backs to the audience at opposite sides of the stage. Suddenly, the sisters emit "un grito desgarrador" and fall to their 
knees. The murder has been perpetrated (98-100). The second instance takes place towards the end of the second act, when Cuca and Lalo, immersed in a heated discussion, role-play their parents. Their argument escalates into violence, only to be interrupted by Beba's euphoric impersonation of Lalo: BEBA. (Como LALO. Gritando y moviéndose en forma de círculo por el escenario.) Hay que quitar las alfombras. Vengan abajo las cortinas. La sala no es la sala. La sala es la cocina. El cuarto no es el cuarto. El cuarto es el inodoro. (BEBA está en el extremo opuesto a $L A L O$, de espaldas al público. LALO, también de espaldas al público, se va doblando paulatinamente. En un grito espantoso.) Ayyyyy. (Entre sollozos.) Veo a mi madre muerta. Veo a mi padre degollado. (En un grito.) ¡Hay que tumbar esta casa! (127)

The game concludes with these words, as Lalo begs for the door to be opened. The sisters briefly discuss the outcome of the game and the play ends, as already mentioned, with Beba's assertion that it is now her turn to lead the game.

Both scenes mark climactic instances of high emotional intensity that problematize the straightforward reading of the phrase as an expression of rebellion. To begin with, it must be noted that Lalo, the character most associated with the phrase and regarded as the leader of the revolt, does not utter these words; it is Beba who puts the phrase in Lalo's mouth through an act of impersonation. Therefore, the phrase's suggestive power is strictly related to the highly emotional dramatic context in which it occurs. In the first act, Cuca faintly sings the phrase before the two sisters emit a horrid cry. In the second act, Beba begins to grunt before her words become intelligible and turn the recurrent phrase into a sweet tune. Soon after, Beba frantically yells the same words, ending her speech with another horrid cry that precedes Lalo's breakdown. The faint singing, sweet voicing, and yelling of "La sala no es la sala. La sala es la cocina" map the emotional state of the characters as they enunciate the phrase. Nonetheless, it is the grunts and cries that precede and succeed these words that truly reveal the emotional intensity that afflicts their bodies. Through their unintelligible quality, these sounds signal the characters' inexpressible despair.

In order to explore the siblings' game as an experience of crisis, I now turn to Elaine Scarry's conceptualization of torture. In The Body in Pain: The Making and Unmaking of the World, Scarry describes torture as an act, a "structure of unmaking" that, in its most basic expression, is an "appropriation, aping, and reversing of the action of creating itself" (21). Scarry bases her understanding of torture as a phenomenological experience on the 
premise that torture obliterates the subject. Once the subject is destroyed, there is no consciousness to recognize the world and thus the objective collapses (the world is unmade) and torture is complete. The imperative and reciprocal relationship between the subject's annihilation and unmaking of the world becomes clearer when Scarry discusses how a familiar space such as a household can become the unimaginable space of torture:

But it is also crucial to see that the two [the human being and weapon] are here forced into being expressions and amplifications of one another: the de-objectifying of the objects, the unmaking of the made, is a process externalizing the way in which the person's pain causes his world to disintegrate; and, at the same time, the disintegration of the world is here, in the most literal way possible, made painful, made the direct cause of the pain. That is, in the conversion of a refrigerator into a bludgeon, the refrigerator disappears; its disappearance objectifies the disappearance of the world (sky, country, bench) experienced by a person in great pain; and it is the very fact of disappearance, its transition from a refrigerator into a bludgeon, that inflicts the pain. (41)

The disintegration of the object represents the collapse of the objective realm. The moment the refrigerator ceases to be a refrigerator and becomes a weapon, fixed structures of reference shatter and the object becomes incongruous with its own functionality. In this instance, the refrigerator could become any other object, but given the context of torture, it will necessarily become an object of punishment. Hence, the objective realm enters a randomized space in which suffering and pain come to be the determining factors, and this predominance of affect over the world of objects indicates that the objective realm has collapsed into the subjective one. Nonetheless, the tortured individual can no longer sustain the frame of subjectivity and crushes under the weight of the collapsed world. Hence, as Scarry notes, this reciprocity between the de-objectified object and the person's awareness of that disjunction inflicts pain and becomes the act of torture itself.

Clearly, in La noche there is no act of torture. However, the process of objective and subjective disintegration that concretizes in a contingent space governed by affect best describes the dramatic action's climactic instances. Having examined the characters' subjective disintegration as spectral bodies occupied by other plural identities, it is now important to focus on the instability of their world. Taking into account Scarry's theorization, I posit that the recurrent phrase "La sala no es la sala. La sala es la cocina" mas- 
terfully synthesizes the collapse of the objective realm in which an object loses its own referential actuality and enters the aleatory dynamics of chaos. Every object can be perceived as another. For instance, the room can be the kitchen, as the objective realm no longer possesses an organizing structure that adequately distributes essence or fixes identity to matter. At the pivotal instances of heightened emotion, the characters' disjointed world equals their own fragmented condition, while their recurrence to grunts and heartrending screams expresses the despair towards that unmade world on which they can no longer rely. The utter collapse of the objective and subjective realms leaves nothing to the characters but a residual stratum of exhaustion, confusion, and unexplainable emotional boredom. ${ }^{10}$

To illustrate this, I would like to refer to one last example of the critical process of disjuncture and collapse in relation to the central event of the murder. This is the only time Lalo pronounces the recurring phrase and he does so in a monologue directed to Cuca, who is pretending to be the district attorney who prosecutes him for his crime:

Si me sentaba en una silla, la silla no era la silla, sino el cadáver de mi padre. Si cogía un vaso de agua, sentía que tenía entre las manos el cuello húmedo de mi madre muerta. Si jugaba con el florero, caía de pronto un enorme cuchillo al suelo. Si limpiaba las alfombras, jamás terminaba, porque se agigantaba un duro coágulo de sangre. (119) Lalo's words describe a shattered world in which every object has disintegrated and has been subsequently reshaped through the burden of emotional distress. In other words, the house has collapsed under the crisis unraveled by the crime. House and crime stand thus as a determining frame that suffocates the characters and infinitely strains them with its emotional demands. I propose that the desire for rebellion, often simplified and misconstrued as an attempt to challenge the parents' authority, is instead a visceral reaction against this asphyxiating space in which the objective and subjective have crumbled into the contingency of delirium and imaginary action. Beba dictates: "¡Hay que tumbar esta casa!" Similarly, Lalo culminates his monologue asserting: "(En un éxtasis musical.) 'Mata a tus padres.' La casa entera, todo, me exigía ese acto heroico" (120). The heroic act, to kill the parents, is essentially a cry to finally execute the crime and transcend the alienating game of perpetual representations that robs the characters of their own sense of self. It is, namely, a cry to reclaim the world's structures, or, in Scarry's terms, to recreate a world that has been unmade. In La noche, the characters are immersed in a world of 
absolute chaos, unfixed boundaries, and disintegrated selves that emotionally presses them to reclaim a house that is a house and a self that is their own.

\section{Revolution and its burden on subjectivity}

I situate the utterly chaotic and disjointed world of Triana's characters within the framework of revolution, understanding revolution as a historical process of violent and radical change dependent on contingent and non-contingent elements. This conceptualization owes much to Franz Fanon's positing of decolonization as a revolutionary process. In The Wretched of the Earth, Fanon argues that the process of decolonization is a "violent phenomenon" through which the violent colonial relationship between settler and native is abolished. Working within the Marxist tradition, Fanon suggests that this "violent phenomenon" promises the end of violent exploitation as such, but historically, as Idelber Avelar rightly points out, continuous new models of neo-colonial oppression demand "a Trotskyite-type permanent revolution" that extends violence infinitely (7). Similarly, in Triana's play, murder does not put an end to the game, but rather prompts the characters to continue repeating their violent actions, which reminds the spectator of the etymology of the word "revolution," which in this play refers to circularity as opposed to its historical meaning of rupture (Ford 111).

Fanon's understanding of revolution, marked by the ubiquity of violence, shows both the contingent and non-contingent character of revolution. On the one hand, revolution is not an accidental phenomenon that occurs fortuitously, but rather a historical development determined, justified, and, most importantly, instigated by specific social, political, and economic situations. This is the rationale behind Fanon's call for decolonization. On the other hand, revolution as a historical process comprises innumerable complexities and variables that cannot possibly be synthesized, analyzed, or fully conjectured through an individual's limited understanding. Hence, there is also a contingent dimension to revolution in which violence always manifests itself in unpredictable ways. Illuminating this dual nature of the revolutionary process, Fanon writes:

Decolonisation, which sets out to change the order of the world, is, obviously a programme of complete disorder (...) Decolonisation, as we know, is a historical process: that is to say that it cannot be understood, it cannot become intelligible nor clear to itself except in the exact measure that we can discern the movements which give it historical form and content. (29-30) 
Fanon's study is in itself an attempt to discern the movements that historically articulate the process of decolonization, but in his wording there is already an implied sense of limitation on details and instances that remain beyond the scope of human reasoning. This paradoxical condition of revolution as a historical process that must be understood in order to be guided and realized, but which through its very nature defies said understanding, speaks to human limitations. Such limitations would appear to be mainly a cognitive barrier, but what they truly represent is a question of agency. The paradoxical character of history makes us question the extent to which a subject can consciously understand and act in a complex and violent historical process such as a revolution.

This fundamental question is examined in La noche through the dramatic lens of performance. In reading Fanon, Avelar insightfully points out that "For the native the process of violently destroying colonialism is not a contingent, unimportant one but rather the very process through which s/he accedes to subjectivity" (7). In Triana's play, the characters' desire for rebellion, which has been described as a visceral reaction against a shattered world, is precisely how they access subjectivity. The siblings' chaotic world is a world that resembles the space of revolution. It is essentially a space of crisis with no stable order that can organize the world into set categories and correspondent identities; a world that has been disrupted by a violent phenomenon set out "to change the order of the world." Within this unstable world, the characters have no coherent ontological unity. The siblings engage in myriad representations in which every instance of role-playing becomes an erratic attempt to fix their own identity beyond the contingencies of performance. Lalo wants to become Lalo, and Cuca and Beba also seek an autonomous self no longer refracted into ephemeral and emotionally-exhausting impersonations. Nevertheless, their vertiginous game only succeeds at perpetuating the violence of their fragmentary condition, and thereby denies them a concrete sense of self and subjectivity.

Fanon further comments on the construction of subjectivity in Black Skin, White Masks, as he examines the ontological experience of black people in a colonized society. He frames his discussion in the Hegelian dialectics of recognition, which posits that self-consciousness exists to the extent that it is recognized and acknowledged by another. ${ }^{11}$ Fanon writes: "Each consciousness of self is seeking absoluteness. It wants to be recognized as an essential value outside of life, as transformation of subjective certainty (Gewissheit) into objective truth (Wahrheit)" (192). The development from subjective 
certainty to objective truth presupposes a sense of ontological coherence that the subject must possess to demand and expect the recognition of another. This assumption is central to Fanon, who argues for black consciousness to be acknowledged in its true essence, beyond colonial parameters and impositions. In his view, it is through these means that the black consciousness could enter the realm of recognition and successfully be concretized as an objective truth.

La noche, however, shows us an extreme chaotic space that precludes consciousness and identity as concrete and formed concepts. The siblings' environment of crisis disables them from asserting their subjectivity and exercising the desire to be objectively recognized. Through them, Triana shows a cruder and darker possibility of human existence. Not only is the subject not recognized by the other on the level of human existence - nothing is further away from Lalo, Cuca, and Beba than the possibility of entering the objective realm of truth - but this subject, failing to account for her own subjective consciousness, cannot experience or express her own concrete existence. This radical ontological condition refers us back to one of Fanon's central questions regarding the subject's ability to act productively in the midst of a historical process.

Through his disoriented characters, Triana answers in the negative. Lalo, Cuca, and Beba are incapable of acting coherently and lack a defined sense of agency. Their actions are erratic, even delirious. The best example is Cuca's unexplained shift between acts from rejection of the game to a vigorous desire to lead the murderous performance. The characters' lack of agency is linked to a deeper limitation related to their cognitive capabilities. The siblings cannot make sense of their chaotic surroundings and fail to understand the game's physical and emotional burden. From this perspective, I posit that Triana's characters are dramatic imaginations of the historical subject unable to comprehend or assertively act within the vortex of history. Ultimately, it is this condition that shatters their subjectivity.

This leads us to conclude that La noche is not as much a play about revolution as it is a play about the effects of revolution. The play examines the radical ontological consequences that revolution can entail. Within its radical performative space there is a dual process of disintegration in which the mutual objective and subjective collapse reflect the ultimate consequences of revolution as a violent historical process. But also tangentially, through Lalo, Cuca, and Beba, La noche details the human desire to understand, organize, direct, and transcend spaces and moments of crisis. From this viewpoint, we 
understand the extent to which La noche speaks about the experience of the Cuban revolution in its brilliant dramatic imagination of the subject and her physical, emotional, and subjective struggle to participate, comprehend, and cope with the overpowering and manifold demands of history.

\section{University of Toronto}

\section{Notes}

1 Quoted by Frank N. Dauster in "The Game of Chance: The Theatre of José Triana."

2 The dramatic action echoes the events of The Libation Bearers in The Orestia, in which Electra and Orestes plan to murder their mother, Clytemnestra, to avenge the assassination of their father, Agammenon. In La noche, however, the matricidal theme becomes part of the representational frame of action, as it is continually enacted or referred to, but never perpetrated. It thus becomes an elusive theme that serves as backdrop for the elaborate scheme of role-playing in Triana's play.

3 The performance was done by Teatro Estudio under the direction of Vicente Revuelta and staged at the Hubert de Blanck Hall. It won the Casa de las Américas award, the highest recognition granted to a theatrical production in Cuba.

4 See Dauster and Julio Miranda.

5 Katherine Ford further explains this reading by writing that "a través del tema de la repetición (la revolución histórica), la obra manifiesta una visión alternativa que se opone a la oficial" (101).

6 See, for example, Matías Montes Huidobro.

7 Revuelta, the director, and the group of actors were invited by the Théatre des Nations to perform in Paris and later in Avignon. The play was also performed at the Biennale di Venezia and toured eight Italian cities. Eventually, the play was translated into twenty-one languages and spread from Africa to the Middle East (Meyran 25).

8 As later explained in this article, Woodyard's perspective shifts toward a more political view that attributes a revolutionary function to Latin American theatre.

9 Critics who hailed La noche as a revolutionary play maintained that Triana, through the representation of a generational conflict, gestured the need for a revolution during Batista's abusive regime. Conversely, those who denounced the play as a counterrevolutionary piece maintained that Triana, through this same conflict, was implying the cyclic nature of revolution and suggesting the future fall of the present one.

10 Taylor also speaks of objective and subjective collapse in her definition of the theatre of crisis: "I refer to crisis in the more general sense of a 'turning point' between death and regeneration, taking into account both the objective systematic shifts or ruptures (revolution, military takeover, wars and civil wars) that affect the nature of the society as a whole and the subjective, personal experience of disorientation and loss of identity" (6). Although I owe much to Taylor's insightful theorization, her employment of these terms develops within a broader framework that situates the theatre of crisis halfway between the European theatre of the absurd and Latin American theatre of protest $(9,52-53)$. My interest is simply to show how in La noche's performative space there is a mutually implied frailty of both the objective context and subjective consciousness.

11 In his chapter "The Black Man and Recognition" he includes the following epigraph taken from Hegel's Phenomenology of Mind: "Self-consciousness exists in itself and for itself, in that and by the fact that it exists for another self-consciousness; that is to say, it is only by being acknowledged and recognized" (191). 


\section{Works Cited}

Avelar, Idelber. The Letter of Violence: Essays on Narrative, Ethics, and Politics. New York: Palgrave Macmillan, 2004. Print.

Campa, Román V de la. José Triana: ritualización de la sociedad cubana. Madrid: Cátedra, 1979. Print.

Dauster, Frank N. "The Game of Chance: The Theatre of José Triana." Lyday and Woodyard. 167-89.

Fanon, Franz. The Wretched of the Earth. Trans. Constance Farrington. New York: Grove Press, 1966. Print.

. Black Skin, White Masks. Trans. Richard Philcox. New York: Grove, 2008. Print.

Fernández Fernández, Ramiro. “José Triana habla de su teatro.” Románica 15 (197879): 33- 45. Print.

Ford, Katherine. "El espectáculo revolucionario: El teatro cubano de la década de los sesenta." Latin American Theatre Review 39.1 (2005): 95-114.

Gladhart, Amalia. The Leper in Blue: Coercive Performance and the Contemporary Latin American Theatre. Chapel Hill: U of North Carolina Department of Romance Studies, 2000. Print.

Hegel, G.W.F. The Phenomenology of Mind. Trans. J.B. Baillie. $2^{\text {nd }}$ ed. London: Allen \& Unwin, 1971. Print.

Lyday, Leon F., and George W. Woodyard, eds. Dramatists in Revolt: The New Latin American Theatre. Austin: U of Texas P, 1976. Print.

Meyran, Daniel, ed. "Introducción." La noche de los asesinos. Madrid: Cátedra, 2001. 3-25. Print.

Miranda, Julio. "José Triana o el conflicto." Cuadernos Hispanoamericanos 230 (1969): 439-44. Print.

Montes Huidobro, Matías. "Máscara familiar: esquizofrenia mágica." Persona, vida y máscara en el teatro cubano. Miami: Universal, 1973. 413-27. Print.

Nigro, Kirsten F. “La noche de los asesinos: Playscript and Stage Enactment." Latin American Theatre Review 11.1 (1977): 45-57.

Plato. Republic. Trans. C.D.C. Reeve. Indianapolis: Hackett, 2004. Print.

Scarry, Elaine. The Body in Pain: The Making and Unmaking of the World. New York: Oxford UP, 1985. Print.

Taylor, Diana. Theatre of Crisis: Drama and Politics in Latin America. Lexington: UP of Kentucky, 1991. Print.

Triana, José. La noche de los asesinos. Ed. Daniel Meyran. Madrid: Cátedra, 2001. Print.

Woodyard, George. "The Theatre of the Absurd in Spanish America." Comparative Drama 3.3 (1969): 183-92.

. "Estorino's Theatre: Customs and Conscience in Cuba." Latin American Literary Review 11.22 (1983): 57-63. 